\title{
FIRST ANNUAL REPORT OF THE BOARD OF CONTROL S.A.T.S. "GENERAL BOTHA." Year ending 14th July, 1922."
}

I. Every race worthy of the name produces youths whose hearts burn with a desire for a sea life and a passion to see other lands. The two chief races of South Africa descend from peoples with great and honourable sea traditions, with which are associated the names of many distinguished admirals and navigators.

The sea sense in the descendants of these two races as now represented in South Africa, perhaps on account of generations-long habitation away from the coast, or a lack of close association with a sea-faring life, has, generally speaking, become dormant. However, notwithstanding the apparent decadence of the sea spirit in the national character, there are amongst the South African youths of to-day numbers of boys possessing an hereditary predominance of that spirit, who travel, and in some cases even walk, great distances to our seaports, from time to time, in search of the adventures of a life on the ocean wave. Unfortunately, such boys upon arrival at our coast ports are faced with disappointed hopes, for, without any previous sea training or experience, or any organised method of dealing with such cases, there is little opportunity of them obtaining any but chance employment at sea. As these adventurous spirits are in many cases of too independent a nature to return home and acknowledge their defeat, they often go to swell the ranks of the unskilled unemployed in the coast towns that drift into side-alley occupations, sometimes falling into bad company, through the lack of guardianship which every boy requires. In future, however, South African boys inspired with a longing for the sea will have some organisation to address for information, advice and help. The establishment of such an institution is due to the foresight of a keen-sighted South African exmaster mariner, Mr. T. B. F. Davis of Durban, who saw what was required and nobly supplied the want out of his own purse by presenting to South Africa a ship to be used as a training institution to fit her boys for a sea career, which ship has been named after a South African whose name will ever hold a foremost and honoured place in the annals of South Africa.

HISTORY

The South African Training Ship "General Botha" was formerly H.M.S. "Thames," a third-class cruiser of the river class, and was built in Devonport in 1886, being used during the latter part of the Great War as a submarine depôt ship; her displacement is 4,050 tons, length over all $324 \mathrm{ft} .2$ ins., beam $46 \mathrm{ft}$., draught forward $19 \mathrm{ft}$., aft $22 \mathrm{ft} .6$ ins.

The establishment of South Africa's first training institution originated in an agitation which took place in Cape Town in 1920 in connection with new quarters for the Cape Town Naval Cadet Corps. Mr. Davis happened then to be in Cape Town

\footnotetext{
* Editorial Note: The first Annual Report of the Board of Control of the S.A.T.S. General Botha is dated the 8th of July, 1922 and after a lapse of 50 years, has become a priceless record of the first truly successful attempt in South Africa at training selected boys for, in the main, subsequent careers in the Mercantile Marine. The language in which the report is couched - even the spelling in places - could have done with improvement, but it would be both presumptious and unjust at this stage, if attempts were made to improve on so intriguing a record, which clearly represents such an important milestone in our Maritime history. The report is accordingly rendered verbatim.
} 
and he at once conceived the idea of giving a ship for the purpose of training South African boys for the sea, as a memorial to his son Howard, who gave up his life on the fields of Flanders during the Great War. In June, 1921, suiting the action to the word, Mr. Davis went to England and purchased the third-class cruiser H.M.S. "Thames," which sailed out to South Africa under her own steam, at the entire expense of the owner, who also defrayed the cost of one officer and twenty boys of the Cape Town Naval Cadet Corps going to England in order to have the experience of bringing her out. The "General Botha" arrived in Cape Town on the 26th March, 1921, where she was berthed pending her formal taking over.

\section{ADMINISTRATION}

II. Trust.- Under the Deed of Donation drawn up by the donor, transferring ownership from him to the three trustees appointed under the Deed (namely, the Prime Minister of the Union (General the Rt. Hon. J. C. Smuts, C.H., K.C., M.L.A.). and the Administrator of the Cape Province (the Hon. Sir Frederic de Waal, K.C.M.G.), both ex officio with power to co-opt a third trustee, who, for the first five years, is the Hon. J. W. Jagger, M.L.A., Minister of Railways and Harbours, who has taken a keen interest in the movement from the first. The actual administration of the ship is vested in a Board of Control.

Donor's Conditions.-The conditions of the trust as laid down by the donor are that the ship shall -

(1) always bear the name "General Botha;"

(2) be used as a training ship for the purpose of training boys of British South Africa for service in ships sailing under the British flag;

(3) be accessible to the boys of the Cape Town Naval Cadet Corps for their peacetime training under such conditions as may be prescribed;

(4) revert to the donor or his estate if the name of the ship be removed or changed, or the ship be not used as a training ship as hereinbefore provided.

Board.-The Rules and Regulations for the administration of the trust are framed by the Trustees and the Board of Control jointly. All other matters and questions affecting the institution are administered by a Board of Control which is appointed annually, the present Board having been constituted on the 14th July, 1921, consisting of four persons nominated by the Union Prime Minister: namely: Sir Roland Bourne, K.B.E., C.M.G., Cdr. E. Delius, O.B.E., R.N. (retired), Captain R. A. Leigh (Port Captain, Cape Town), and G. Owen-Smith, Esq., in his capacity as the head of the department having the Control of Shipping; three persons nominated by the Central Organisation of the Navy League of South Africa, namely, Capt. W. R. Butters (Lt.-Cdr. R.N.R.), E. M. O. Clough, Esq., C.M.G., and J. S. Dunn, Esq., C.B.E., one person appointed by each of the following, namely:-

(a) Naval Commander-in-Chief Africa Station: Lt.-Cdr. Marshall Clarke, D.S.C., R.N.

(b) The donor or his executors: A. N. Payne, Esq.

(c) The officers of the Cape Town Naval Cadet Corps: Dr. A. P. Moore Anderson.

(d) The officers of the Durban Naval Cadet Corps: Capt W. G. Mathie and

(e) Executive Committee of the Boys' Naval Brigade, Johannesburg: Lt.-Col. J. G. Rose, D.S.O.,

its officers being Mr. Clough (Chairman), Mrs. R. A. Bennett (Secretary) and Mr. 
The Trustees and the Board met in joint meeting on the 14th July, 1921, for the purpose of electing the Chairman and officers, and at their next meeting adopted rules for their own procedure and for the regulation of their finance.

The Board then commenced its operations, which have involved 41 meetings, in addition to many other enquiries conducted both by its technical and non-technical members, which has necessitated members giving up a very considerable part of their time in the establishment of the institution. The services of every member of the Board have not only been voluntary, but each one has paid all his own out-ofpocket expenses.

\section{NATURE OF INSTITUTION}

III. The ship is to be stationed at Simonstown and is a moored training ship for the purpose of training 150 boys afloat for the sea.

One of the first resolutions of the Board was to lay down that the ship should be kept free from anything which may give the impression that it is an institution of a reformatory industrial school, or disciplinary-corrective nature, and that, in the selection of boys for training, only those of guaranteed good character would be accepted. The ship is an institution for the training of boys principally for the mercantile marine, but arrangements have been made by which a number of boys may, with the consent of their parents, volunteer to join the Royal Navy as seamen should they so desire..

\section{SELECTION OF BOYS}

IV. It was next decided that the ship should only be open to South African boys of European descent, between the ages of 13 and 15 years, who have their parents' consent and are of prescribed physical fitness, of guaranteed good character, who have passed educational Standard VI., and that, in order to continue that happy co-operation between the two white races of the Union which is bearing such fruitful results from year to year, the boys be accepted, so far as possible, in the proportion of 50 per cent. Dutch- and 50 per cent. English-South African origin, preference being given, subject to such proportion of 50 per cent., to boys who come of sailor stock or have served in any of the South African sea-cadet units, and that ignorance of either the English or Dutch language shall not disqualify any applicant. It was discovered later, however, that whereas the average maximum age of town boys who had passed the said standard was 15 years, the average maximum in the country was 16 years. In order, therefore, to give the country boys equal opportunity with the town boys the maximum age was afterwards raised to 16 years, which alteration had the effect of increasing the number of Dutchspeaking applications. The Board then issued a printed memorandum setting forth the objects of the institution, conditions of entry, the training, employment after training, and a scheme for the after care of the boys when they leave the ship for the necessary continuance of their career at sea. Between the 15th September, 1921, when applications were first called for and the 30th November, 1921, the latest date for receiving them, 1,005 applications were received from all over the Provinces of South Africa.

The Board then appointed a committee from amongst its number to go into the applications and to select therefrom the 75 best boys having in mind the proportion of 50 per cent. above-mentioned. This committee held several meetings and in its report stated that, of the 1,005 applications (approximately one-third of which were of Dutch-South African origin), 811 were disqualified on one or other of the following grounds:- 


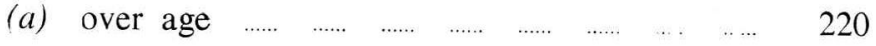

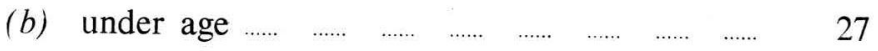

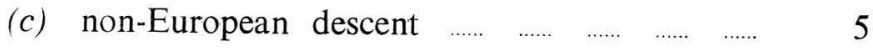

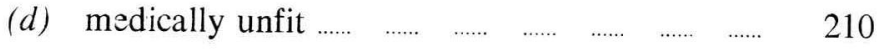

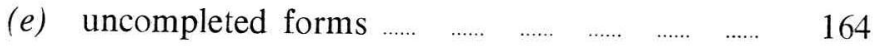

(f) educational disqualification $\quad \ldots \ldots . . \ldots \ldots \ldots$

$\begin{array}{ll} & \\ \text { Applications remaining for consideration } & 811 \\ 194\end{array}$

As it could be seen that the number of English-South African applications considerably exceeded the Dutch-South African applications, the committee put all the English applications on one side and proceeded first with the Dutch applications, from which they were then able to select 18 eligible applicants, both of whose parents were Dutch. The committee then went through all the remaining applications, and were able to select 5 eligible applicants, one of whose parents was of Dutch origin. Five selections were then made of boys coming from "sailor" stock and four strongly recommended by the O.C. of their particular S.A. Naval Cadet unit, as having had some sea training. 32 English eligible applicants were then selected. In the event of the applicants falling out for any reason the Committee placed 11 other applicants upon a reserve list, leaving a balance of 5 wherewith to provide certain outstanding bursaries. By accepting late applications from Dutch applicants, upon English-speaking applicants falling out on medical and other grounds, the Board was able to increase the number of Dutch-speaking boys to 33 out of 75. It is hoped, however, that sufficient eligible applicants will be accepted for training for the second two years' course, as to enable the abovementioned 50 per cent. proportion of the whole 150 to be obtained. It will be observed that by only selecting 75 boys each year there will always be, after the first year, 75 oneyear boys in the ship when each lot of 75 new boys embark upon their training, thus helping the new boys through the first year's course.

The boys now undergoing training come from the Provinces of the Union in the following proportions:-

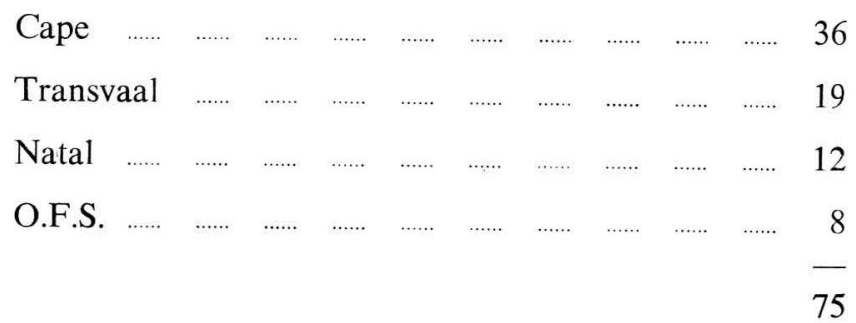

Consequent upon the recent visit of the Rhodesian Delegation to the Prime Minister of the Union at Cape Town the Southern Rhodesian Administration on the 19th May, 1922, voted the entire cost of upkeep of 4 of their boys for the two years' course in the ship, and arrangements have been made to accept such boys and help them catch up with the 75 boys whose technical training began on the 15th March last. The Rhodesian boys, if available in time, will bring the first year's complement up to 79 . 


\section{APPRENTICESHIP CONTRACT}

V. In order that a boy may not be frivolously withdrawn during his training and the berth vacated by him thus be wasted for the entire two years' course, the Board made provision, in a contract entered into with each parent, whereby compensation could be claimed by the Board for the maintenance of the ship in respect of such wasted berth. Therefore, it will not be possible for a boy to be released from the contract of apprenticeship before the completion of the two years' course, unless his discharge has been purchased by his parent or guardian at the price laid down by the Board (which is reckoned only at the annual cost of the boy's feeding, clothing, medical attendance and equipment), namely, $£ 72$ if the boy is withdrawn by the parent or guardian in the first year, and $£ 144$ if withdrawn in the second year. The Board, however, reserves to itself the right to reduce or waive such sums in cases where the reasons are considered valid by the Board.

\section{TRAINING AND EDUCATION}

VI. In the system of the training and education of the boys during the two years' course the Board decided, after careful and mature consideration, that the ordinary general, or, as it will be described herein, "non-technical," education of the boys be continued in the same respect as if they had remained at school ashore; but with the addition of the mathematics and science required by Board of Trade examination for Masters and Officers of the Mercantile Marine; and that the nautical training, or, as it will be referred to herein, the "technical" education, be carried on concurrently with the non-technical education, in that way fitting the boy for after life should he for any reason not be able to continue his career at sea at the close of his training.

As the ship does not accept boys until they have passed Standard VI. it is, according to the educational classification, a secondary school, and nautical training having been accepted by the educational authorities as technical training, the ship, as an institution, also becomes a technical school.

Term.-Owing to the great distance many of the boys have to come from their homes, and the unsettling effect which term vacations in the year would have upon them, but principally because every boy has not only to continue with his studies, just as if he remained at school on shore, but has, in addition, also to go through his technical education, it was decided to have one unbroken term per annum which begins on the 15th February and closes on the 15th December, thus giving every boy an annual vacation of two months.

Instructional Language.-For the purpose of the non-technical education every parent was invited by circular letter to express his views as to which medium was desired. The invitation, however, did not apply to the technical training, as in the first place it was thought that English would be a more useful language to every boy in his after life at sea, and in the second place technical teachers with a bilingual qualification were not obtainable.

In regard to the technical and non-technical education the Board, in consultation with educational authorities, agreed upon a syllabus to cover both branches of the education and avoid overlapping. Under this system each boy will be given an opportunity at the end of his course of taking his secondary school Junior Certificate, with the additional mathematics and science as beforementioned, as well as qualifying for a First Class Extra Certificate for Seamanship.

On account of the difficulty in obtaining qualified schoolmasters the non-technical education was not commenced until the 15th April; but the technical education under the Captain and Chief Officer, assisted by four instructors of the ship, began 
directly the boys joined the ship on the 15th March last. Both the Captain (an ex"Conway") and the Chief Officer (an ex-"Worcester") boy hold their Master Mariner's certificates, and the Captain an extra Master Mariner's certificate, in addition to other qualifications. Of the instructors, three have been seconded from the Royal Navy for two years to instruct in signalling, seamanship, gunnery, drill, etc., the physical training instructor being an ex-instructor of the 1st South African Infantry.

Curriculum.- The curriculum for technical and non-technical education is as follows:-

\section{PHYSICS}

Mechanics.-Units, velocity, acceleration, bodies falling from rest, uniform acceleration, Newton's first and second laws, work, energy, and power, composition of forces, moments, parallel forces, centre of gravity, Archimede's principle, the hydrostatic balance, determination of specific gravities by the hydrostatic balance, atmospheric air, barometer, Boyle's law.

Heat.-Nature of heat, expansion, temperature, thermometry, co-efficient of expansion, specific heat, change of state, latent heat, transmission of heat, conduction and convexion.

Light.-Nature of light, rectilinear propagation, shadows, images, laws of reflection of light, refraction, dispersion.

Electricity.-Conduction and insulation, potential, the production and detection of currents, Ohm's law, batteries, constant cells, electrolysis.

\section{MATHEMATICS}

Algebra to simultaneous equations, simple and compound interest, vulgar and and decimal fractions, ratio and proportion, square and cube roots, graphs and metric system, coinage, percentage, profit and loss, areas and volume.

Geometry.-Fundamental notions of volume, surface, dimensions, lines and points, and of direction parallel lines, angles. Construction of perpendiculars, parallels, triangles, and quadrilaterals from given data, construction of angle equal to given angle, construction of tangent to a circle from point on circumference or outside. Proofs of geometrical theorems.

\section{GEOGRAPHY}

Physical and Political.-The seasons, zones of climate, tides and currents. Map reading, including calculations of distances from scale, and the drawing of sections from a contour map. Trade routes, winds and currents. Phases of the moon. The trade relations of South Africa with the world. Exports and imports of the various countries. Geography of South Africa (south of the Zambesi), and of Europe broadly considered with reference to the following: (a) Physical relief; (b) Climate and rainfall; (c) natural regions; $(d)$ resources, plants, animals, minerals, products and industries; $(e)$ political divisions or control.

\section{NAVIGATION}

Logarithms, plane and spherical trigonometry, chart work, explanation and use of sextant, day's work, latitude by meridian altitude of sun, star, planet and moon, ex-meridian altitude and Pole Star. Longitude by chronometer, error of chronometer, ascertaining errors of compass, Mercator's and plane sailings, magnetism, meteorology. 


\section{HISTORY}

South African.-European settlement - a result of trade enterprise; the origin of the Burgher class; the rule of the Netherlands East India Company; the expansion of the settlement; slavery; the Hugenots; the British occupation - a result of the Napoleonic Wars; the British Settlers; pioneering; the Great Trek; Natal; the Free State; the Transvaal; political changes leading to the Act of Union; the native peoples.

Modern history from the Renaissance to the present time, including Naval and Mercantile Marine history.

Duties of the citizen - in the home, in society and in the State; government central, provincial and local; the passing of laws and the duties of the police; justices of the peace, magistrates and judges in administering the laws.

\section{SEAMANSHIP}

Management of boats under oars and sails; knots, bends, splices and hitches; steering, Morse, semaphore, Naval and International codes; rule of the road at sea; sail-making; lead and log lines; purchases and the lifting of heavy weights; rigging and sails; compass; mixing of paints; anchors and cables; bending and unbending of sails; rigging of sheer legs and derricks; shipbuilding, management of a vessel at anchor in a tideway, clearing foul hawser, docking and undocking ship, stowage of cargo.

\section{DRILL}

Instruction in wearing leather gear, explanation of rifle and bayonet, position of attention; salutes; movements of rifle on the march, forming fours, turning about with arms at the slope and secure on the march. Trail from the slope, turning about at the trail, changing arms at the trail, shoulder from the slope and vice versa. Stepping off and bringing arms to the shoulder. Fixing bayonets on the march. The high port, squad and company drill. Rifle and pistol firing. 4.7 and $12 \mathrm{pdr}$. 12 cwt. gun drill - stripping, explanations of mountings, various parts, uses, explanation of elevating and training gear. Tracing a gun circuit, main and auxiliary percussion firing and its safety arrangements, recoil and run out. Stripping Q.F. blocks and explanation of locks, strikers, box slides and probable causes of missfire. Explanation of B.L. block gun drill and loader; ammunition and explosives, propellants, where found and how used; principle differences between them. Why cordite is a better propellant than powder. Different sort of projectiles. Different firing of shells, markings, charges Q.F. and B.L. principal markings, care and precautions, charges entered into guns, hot and cold. Tubes, fuses, primers, different kinds in use and where used; small arm ammunition, marking of cases, stowage of shells, gauging and examination of shell. Explanation of sub-calibre firing. Description of fireworks of various types, how used and where stowed. Magazines, gunnery lectures, communication drill, sight setting.

Classes.-For the purpose of education the boys are divided into six classes and periodical examinations are held during the course for the purpose of testing the progress made by each boy.

Watches.-For ship's purposes the boys are divided into two watches, Port and Starboard, and each watch into four divisions, forecastle, fore-top, main-top and quarter-deck, each division being under its own instructor. These divisions wash down decks, etc., supply guards and perform all ship's services, drawing stores, manning boats, etc. 
Routine.-The daily routine of the boys is laid down in Schedule C by Regulation No. 34 and is as follows:-

5.45 a.m. Call hammock stower.

6.0 a.m. All hands watches alternately wash, lash up and stow hammocks.

6.25 a.m. Both watches for exercise - Fall in.

6.30 a.m. Scrub and wash decks.

7.15 a.m. Clean guns.

7.40 a.m. Secure.

7.50 a.m. Cooks.

7.55 a.m. Stand by tables.

8.0 a.m. Breakfast.

8.45 a.m. Clear up decks.

9.0 a.m. Divisions Prayers.

9.15 a.m. Technical drill and instruction.

9.50 a.m. Secure rig school.

10.0 a.m. General education.

11.50 a.m. Unrig school.

11.55 a.m. Cooks, stand by tables.

Noon. Dinner.

12.50 p.m. Clear up decks, rig school.

1.0 p.m. General education.

2.50 p.m. Unrig school.

3.0 p.m. Technical education or drill.

4.50 p.m. Secure, clear up decks.

4.55 p.m. Cooks, stand by tables.

5.0 p.m. Tea.

5.40 p.m. Clear up decks.

5.55 p.m. Monday and Thursday, rig school.

6.0 p.m. Tuesday and Friday, scrub and wash clothes.

7.0 p.m. Unrig school or up all wash clothes.

7-8.30 p.m. Stand easy.

8.30 p.m. Cocoa and biscuits.

8.50 p.m. Clear up decks.

8.55 p.m. Stand by hammocks.

9.10 p.m. Prayers.

9.15 p.m. Pipe down.

9.30 p.m. Rounds.

and the general routine classes as laid down in Schedule K by Regulation No. 45, as follows:- 


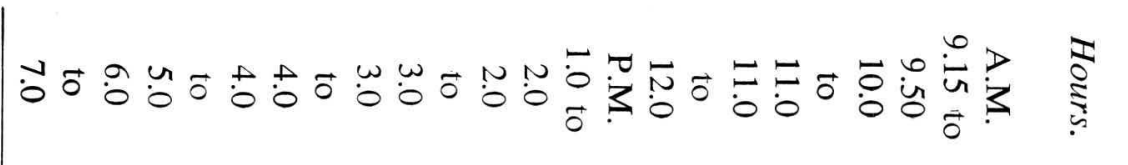

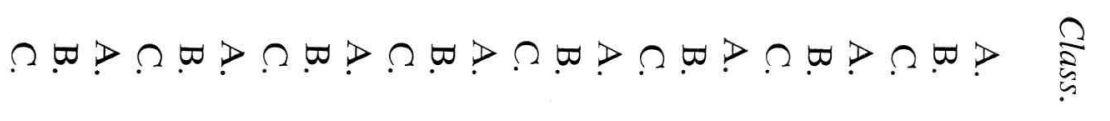

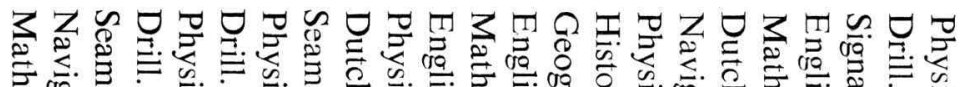

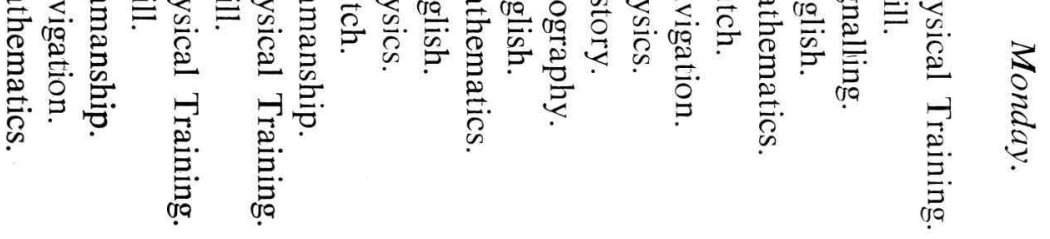

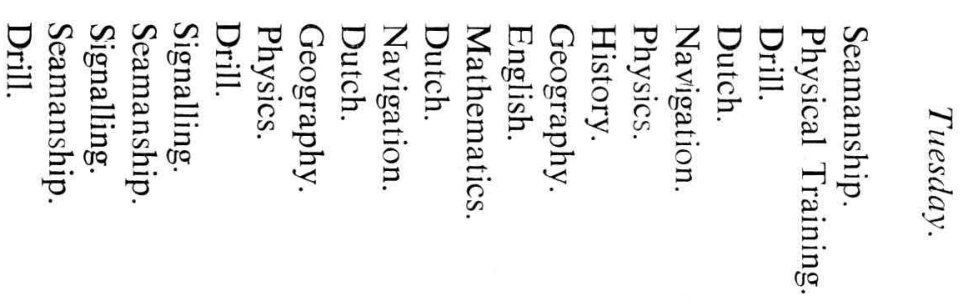

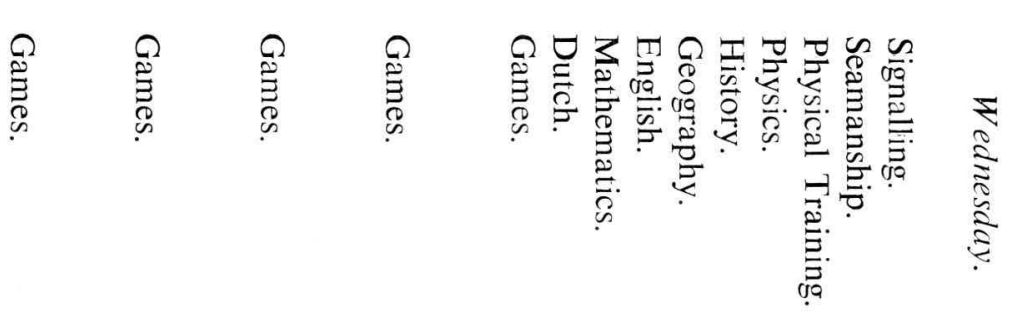

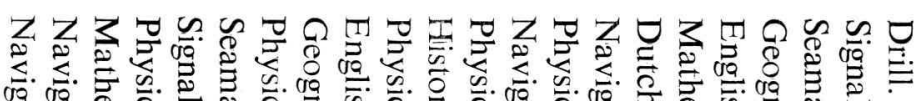

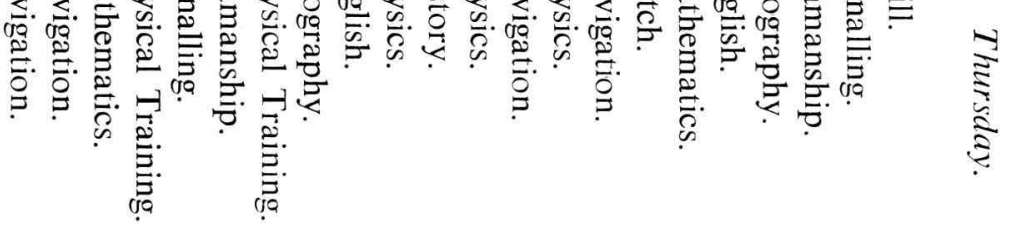

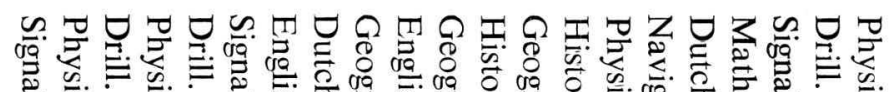

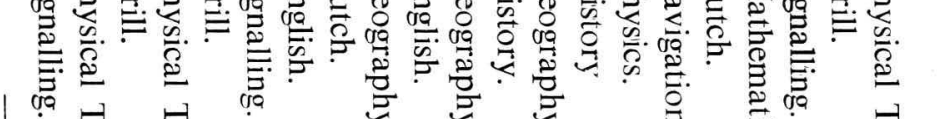

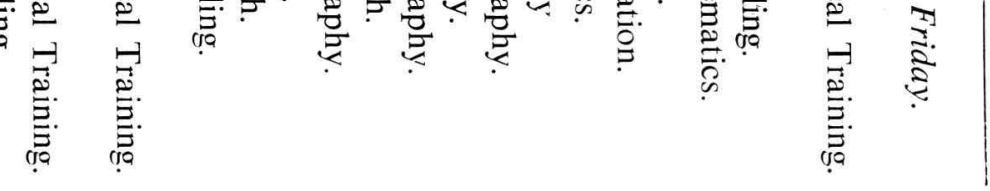

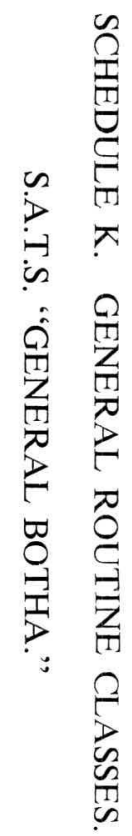




\section{DISCIPLINE}

VII. One of the first duties of a sailor is a firm and well-established sense of discipline. The safety of passengers and crews on the high seas cannot be ensured unless discipline is understood and enforced. Based upon the practice in other training ships of a similar nature, the Board, therefore, has provided for a series of punishments to meet breaches of discipline, and the Captain has been vested with the necessary authority, the punishments being laid down by Regulation No.

23, Schedule B, as follows:-

No punishment is to be administered on the spot; complaints to be heard next day.

No canes to be carried by Instructors.

No. 1 Punishment.-Turn out half-an-hour earlier and stand on deck (limit 7 days).

No. 2 Punishment.-Stoppage of pocket money.

No. 3 Punishment.-Extra drill, squad with arms.

No. 4 Punishment.-Stoppage of recreation and shore leave.

No. 5 Punishment.-To have meals at defaulters' table, turn out half-an-hour earlier and stand on deck, leave and pocket money stopped.

No. 6 Punishment.-To have meals at defaulters' table, to stand on deck for halfan-hour during the dinner hour, to do half-an-hour's drill during recreation time, turn out half-an-hour earlier and stand on deck, leave and pocket money stopped (not to exceed 14 days).

No. 7 Punishment.-To be kept apart from the other boys except during working hours, to mess separately and be allowed only the service rations and forbidden to deal with the canteen. Caning not to exceed 12 cuts and not less than 6 , according to the gravity of the case and to be inflicted only by the actual order of the Captain for serious offences, and is not to be carried out in public but to be witnessed by the Captain or the Chief Officer.

No. 8 Punishment.-Dismissal (the boy to be isolated until instructions received from Board).

Nos. 1, 2 and 3 can be administered by the Chief Officer.

Nos. 4, 5, 6 and 7 can be administered by the Captain.

No. 8 subject to the Board of Control.

Both before and after a boy is given the cane a medical examination is to be made.

With boys full of a love of adventure, as boys seeking entry to the ship must necessarily be, they are naturally high-spirited, and although every opportunity by means of sport and exercise is allowed the boys to work off their superfluous energies yet it is only natural that they will sometimes, on the spur of the moment, transgress. No institution of this nature, however, can be carried on without discipline, firmly but fairly administered.

Due allowance, however, was made at the beginning of the course for boys novel to their surroundings, and discipline, during that time, was judiciously applied, until the boys came to understand how great the value of a true knowledge of it will be to them, in its application to others, when in later life they attain positions of responsibility at sea. 


\section{MORAL AND SPIRITUAL WELFARE}

VIII. The moral and spiritual welfare of every boy is the keel upon which the institution has been laid.

Prayers are held every day on board, each boy enjoying religious freedom. Silence is also observed for each boy to pay his own devotions before "Pipedown" at 9.15 p.m. Religious Service Parades are held on Sundays, each boy attending his own Church, so far as the Churches in Simonstown are concerned, and every boy is under the surveillance of the local Minister of the Church to which he belongs, who also has opportunity to visit him.

Boys are not allowed to smoke or use obscene language. In fact, the Board, throughout their whole policy of carrying out the duty of temporary guardianship of the boys, has taken every possible step and precaution to maintain a high standard of moral and spiritual welfare amongst the boys, in order that the ship may earn a standard of honour which it is hoped will be commensurate in some degree with that of the great South African whose name she bears. For that reason very stringent provision has been laid down in the Rules in order that only boys of good character, especially for honesty and good behaviour, can be accepted. In fact, during the whole course of their training, the boys' moral welfare and physical condition is as scrupulously cared for as if he were in his own home, and the Board will have its reward, if life on board proves to be such that boys in after years will look back upon their course of training as two of the happiest years of their lives. It is one of the aims of the Board that the ship shall earn a good name amongst the sea-faring men of the world, and that a high standard shall always be attached to a "Botha boy," wherever he may present himself. The Board also realises that in order to build up a reputation for this new institution the very greatest care must be taken to preserve the moral standard of the boys.

IX. Leave.-Except during the annual vacation as beforementioned, no free leave is granted any boy, and no boy is allowed ashore, even when on duty, either for work or sport, except in charge of an officer or instructor. In order, however, to give the boys some relaxation and a stimulus in their work, the Board is experimenting with a practice by which boys (except a small number taking turns and kept on the ship for fire and boat duty) may visit each month in the Peninsula, the homes of their parents, relatives, or friends approved of by their parents, of whom the Captain has previously to be furnished with full particulars. This monthly leave is from Saturday noon to Sunday evening muster.

Those boys who have no homes to visit have places provided for them by members of the Board of Control (who take boys to their own homes) or by members of the Ladies' Committee of the Cape Town Branch of the Navy League of South Africa. The host of every boy, however, is previously communicated with by the Captain on each occasion, which letter has to be previously acknowledged, cautioning such host that he is responsible for the care of the boy entrusted to him. Each host is required to meet his boy on arrival at the station and see him off on departure, signing his name and stating the time on the Leave Warrant, which is handed in to the Captain upon the boy's return. An instructor also accompanies the boys on the train both on the outward and homeward journey. Up to the present such guardianship has been satisfactorily performed in every case, and so far as the boys' conduct on these occasions is concerned it is best referred to by stating that the hosts taking boys have asked to be sent boys regularly. Should any host fail to carry out, according to the letter, the instructions given him, his name is erased from any future list. Boys on such monthly visits are not allowed to go about without their host or some member of his family. The Board, therefore, does all that is possible to ensure the boy's moral safety during such leave. 
Visits.-After a boy has been one month in the ship he may be visited, at the discretion of the Captain, on the prescribed visiting days twice a month by his parents or guardians, or friends approved by them, who will apply to the Secretary of the Board for a visiting pass.

\section{RATIONS}

X. The weekly ration of each boy is provided for by Regulation No. 35, Schedule $\mathrm{D}$, as follows: -

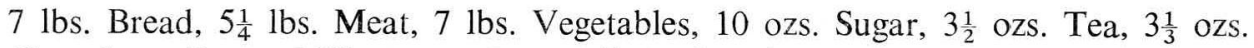
Chocolate, $4 \frac{1}{4}$ ozs. Milk, 7 ozs. Jam, 1 lb. Fish, 3 lbs. Flour, $\frac{3}{4}$ lb. Rice, $\frac{1}{4}$ lb. Oatmeal, $\frac{3}{4}$ lb. Butter, $\frac{1}{2}$ lb. Syrup, $\frac{1}{2}$ lb. Suet, $\frac{1}{2}$ lb. Dried Fruit, 2 ozs. Salt, $\frac{1}{4}$ oz. Mustard, $\frac{1}{2}$ oz. Curry Powder, $3 \frac{1}{2}$ ozs. Coffee. (This is varied according to the seasons).

The appearance of the boys themselves and the fact of the record showing a considerable increase in the weight of each boy, notwithstanding the active life he is leading, proves for itself that the boy is receiving sufficient and nutritious food.

\section{MEDICAL ATTENDANCE}

XI. Medical attendance for each boy is free. According to arrangements made by the Board, the District Surgeon visits the ship weekly. There is also a sick bay on board, under the care of a qualified sick bay steward, to deal with minor cases of accident and illness. Serious cases are treated at the Wynberg Military Hospital, under arrangements made with the Public Health Department. Dental treatment is carried out in Simonstown, but is only free in respect of extractions. All other dental requirements, however, can be performed at a mocierate charge, under a contract arranged for by the Board, but at the cost of the parents.

\section{PHYSICAL DEVELOPMENT}

XII. Upon the 24th March, 1922, soon after joining, each boy was weighed and measured, and on the 13th June, 1922, such measurements and weights were again taken and they all show considerable increase and development, even during that short time.

\section{OUTFIT}

XIII. Regulation No. 40 in Schedule G thereof, lays down the kit supplied to each boy, which comprises every article of clothing, head and foot gear and equipment.

\section{EMPLOYMENT FOR BOYS AFTER TRAINING}

XIV. Royal Navy.-Early in the year 1924 there will be 75 boys awaiting discharge from the ship to continue their service at sea. Of this number 25 may offer themselves for service as seamen in the Royal Navy and obtain such promotion as their capabilities will enable them to win.

With respect to these boys it is hoped that arrangements will be made for them, after entry into the Royal Navy, to remain in South African waters until they reach 19 years of age, when they will be required to take gunnery and torpedo courses in the Admiralty's training schools in England.

Although boys from the institution will only join the Royal Navy as seamen, promotion to commissioned rank is eventually obtainable by boys who can pass the necessary examinations and satisfy the naval authorities as to their fitness and capacity, which with the education received in the "General Botha" they should be well fitted to do. 
Mercantile Marine.-It must be clearly borne in mind, however, that the ship as an institution is primarily for the training of boys for the Mercantile Marine. In respect of the 50 boys remaining of the annual output of 75 , or so many of such 50 as pass out of the ship sufficiently high and are recommended as fitted to become officers, the Board hopes to place its apprentices in shipping lines principally engaged in the South African trade. Parents of such boys, however, will be required to provide the usual outfit, approximately $£ 100$, and also supply their boys with pocket money during their three further years at sea, previous to obtaining their second mate's certificates which will put them in a position of earning a livelihood. In many of the shipping lines such cadets receive a nominal salary during their three years' and some lines require a premium to be paid for the three year's indentures, varying from $£ 30$ to $£ 100$.

Before the discharge of the first batch of boys it is hoped that arrangements will have been made with the Imperial Board of Trade (as in other training institutions of a similar nature) for the two years' training in the ship to count "as one year at sea" for the purpose of the Board of Trade Examinations. It is possible for the boys then, after serving three years at sea in an ocean-going vessel, to go up for their second mate's certificates and, after serving the necessary time as an officer, pass for Mate and ultimately for Master Mariner (Captain of a ship).

Negotiations are going on with a view to some of the boys who have passed out of the "General Botha" being employed upon Union Government merchant ships and in the vessels of shipping lines engaged principally in the South African trade. By the time such boys have gained their respective officer's certificates in the Mercantile Marine, it is hoped that employment as such will be available to them on the ships and vessels abovementioned until, in time, all ships engaged principally in the South African trade carry at least a large percentage of South African officers.

In regard to South Africans serving in the Royal Navy either trained in the "General Botha" or not, it is hoped that arrangements may be made with the Admiralty for such South Africans, whether serving as officers, or as other ratings, to be given an opportunity of being drafted to the Africa Squadron until, in time, such a squadron is largely officered and manned by South Africans, thus building up a Reserve wherewith to protect our shores and ships in case of attack.

As boys joining the Mercantile Marine gain their officer's certificates, it is hoped that when any position under the Government falls vacant for which such qualifications are required, that they will have opportunity of being considered for appointment.

The course in the ship is a strenuous one, as the curriculum has shown, and boys trained in the ship will be competent easily to complete their studies at sea after leaving the training ship.

The employment of the boys, both after training and later when they become qualified, will be greatly influenced by the reputation the ship earns in the seafaring world, and that reputation will not be obtained unless the Board continues to make stringent selection of the best material which South Africa can offer and also takes great care, in granting to each boy upon discharge, no higher certificate than that to which he is entitled, both as regards efficiency and character.

\section{AFTER CARE}

$\mathrm{XV}$. The Board does not propose to let its interest in a boy lapse after the conclusion of his training in the "General Botha," whether he select to join the Royal Navy or the Mercantile Marine, for it is proposed to institute a system of rewards 
to boys who pass into the advanced class of the Royal Navy or who remain at sea for five years in the Mercantile Marine with very good characters, or who reach warrant or commissioned rank in the Royal Navy, or who pass for second mate into in the Mercantile Marine.

The Board hopes to keep in touch with boys in their after career and to encourage visits from old boys at the Board's office and on board the ship, where they will be gladly welcomed. A "General Botha Old Boys' Association" will also be founded (to which only boys who remain throughout the whole course will be eligible). It is the intention also to establish an annual magazine contributed to by the boys, in order that they may learn something of what has happened to their colleagues on the same two years' training course and generally know how "Botha Boys" are faring on the sea.

\section{FINANCE}

XVI. The present financial position of the institution is that excluding capital expenditure, it was estimated that the cost of maintaining the ship as a nautical training institution for the first complement of 75 boys would amount to $£ 14,000$ for the first year. Of this sum the Union Government contributed $£ 7,000$. The Southern Rhodesian Administration will also contribute the entire cost of four Southern Rhodesian boys, i.e., 4/150ths of the total cost of maintaining the ship, amounting to a total sum of approximately $£ 492$ p.a. There has not been time, however, to select such boys for the present year's course. A system of inviting municipalities, public societies and private individuals to contribute bursaries was instituted at the outset, such bursaries to cover the cost of clothing, feeding and equipping one boy, which was estimated, for the two years' course upon a complement of 75 boys, at $£ 144$. Notwithstanding the fact that South Africa is going through a period of financial depression, eighteen of these bursaries have been received, for the first two years' course, namely from:-

Municipality of Maritzburg.

Municipality of Grahamstown.

Municipality of Port Elizabeth.

Municipalaty of Pretoria.

Municipality of Cape Town (2).

Mayor of Kroonstad.

Sons of England.

W. Greenacre, Esq., M.L.A. Senator the Hon. C. G. Smith.

\author{
Standard Bank of S.A. \\ National Bank of S.A. \\ Navy League of S.A. (Cape Town). \\ Navy League of S.A. (Durban). \\ Chamber of Mines. \\ Fairhaven Work Party. \\ J. Garlick, Esq. (Cape Town). \\ Chamber of Commerce (Durban).
}

There were also four Durban bursaries promised, but the boys have not yet been selected, therefore the number of bursaries in respect of which boys are actually on the ship is 18, which at $£ 144$ amounts to a total of $£ 2,592$ for the two years' course, leaving a sum of $£ 1,296$ available for the expenses of the current year in respect of such bursaries.

An invitation was made last Union Day to all Mayors of Municipalities in the Union of over 2,000 inhabitants for the raising of the necessary sum, to complete the total cost of maintenance of the institution, by means of Flag Days, subscription lists, etc. His Royal Highness Prince Arthur of Connaught graciously allowed an appeal from himself to accompany such invitation as well as making a donation to the funds. The result of this appeal is not yet known, although intimation has been received that many Municipalities are taking the necessary steps. Small contributions from private persons are also being received, but these have not yet amounted to more than $£ 225$. 


\section{SHIP'S STAFF}

XVII. The ship's technical staff consists of the following:-

The Captain,

3 Officers (Chief Officer, Purser and Engineer),

4 Instructors,

4 Cooks,

2 Stewards,

Night Watchman,

Sick Bay Steward,

2 Carpenters,

Greaser,

Sculleryman,

at a cost of $£ 4,186$ per annum. In addition to salaries all the staff have quarters and rations free on board and, with the exception of the Captain and Officers, all are provided with uniforms.

Excluding Capital Expenditure, the estimated cost of running the ship for the current financial year with its present complement of 75 boys and a staff of 25 is detailed as follows:-

Ship's Staff

Rations for 294 days at 2s. 3d. per day

Electric Light and Pumping Plant

Water, 201,500 gals. p.m. at 1s. per 2,240 gals.,

$35 \mathrm{~s}$. per hour for transport

Uniform and equipment-

Badges, Trimmings (Officers)

Ship's Staff (other than officers)

Boys'

200

2,000

Maintenance of vessel (painting, cordage, cleaning gear, carEducationpentering, coal and other stores and fittings)

$\begin{array}{rrr}£ & \text { s. } & \text { d. } \\ 4,186 & 0 & 0 \\ 3,628 & 13 & 0 \\ 324 & 0 & 0 \\ & & \\ 238 & 0 & 0\end{array}$

Staff of 2 teachers at $£ 540$ and $£ 285$, Books and Instruments at $£ 300$

\begin{tabular}{rrr}
1,125 & 0 & 0 \\
\hline 13,331 & 13 & 0
\end{tabular}

For the full complement of 150 boys as and from the 15th February next, the abovementioned such should only require the addition of the necessary sums for clothing, feeding and the cost of extra non-technical teachers and ship's officer respectively. It is difficult, however, to estimate accurately what the actual annual cost of maintenance will be until it has been ascertained by actual practice. After the first year, experience will no doubt contribute towards economies in many directions.

\section{CAPITAL EXPENDITURE}

XVIII. In addition to the Admiralty estimate of $£ 4,984$. $18 \mathrm{~s}$. 7d. paid last financial year for carrying out the repair and refit of the ship, the following sums have been incurred upon capital and initial expenditure and will require to be paid in order to fit the ship out, which sums cannot be fairly classed as ordinary running expenditure, namely:- 
Converting of ship $£ 12,019$ 0s. 4d., less $£ 9,894$ 18s. 7d. paid during last financial year

Naval Stores (Hammocks, Boat Gear, Ropes, etc.) ...... .............

Victualling stores( mess utensils, cooperage, carpenters' and engineers' tools)

$2,124 \quad 2 \quad 4$

$1,459 \quad 0 \quad 10$

Armament Stores

$3,327 \quad 10 \div 9$

$\begin{array}{lll}520 & 10 & 9\end{array}$

$£ 7,431 \quad 8 \quad 7$

Less initial outlay for uniform and clothing

$2,148 \quad 13 \quad 7$

$£ 5,282 \quad 15 \quad 0$

XIX. The estimated revenue is as follows, excluding the total annual contribution by the Administration of Southern Rhodesia in respect of four boys to be sent by them, of $£ 492$ p.a. and in respect of non-technical education contributions to the funds of the Board:-

Union Government

$£$ s. d.

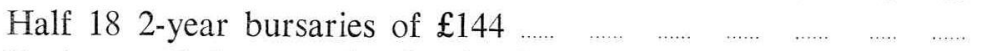
$7,000 \quad 0 \quad 0$

$1,296 \quad 0 \quad 0$

Rations and Quarters for 2 schoolmasters at £5 per month $\quad \begin{array}{lllll}120 & 0 & 0\end{array}$

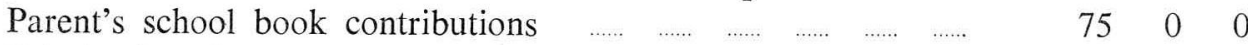

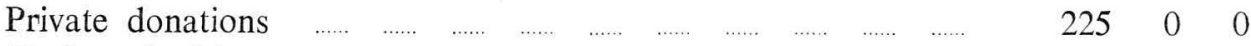

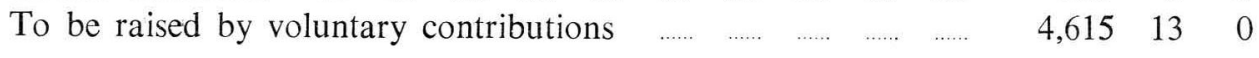

$£ 13,331 \quad 13 \quad 0$

\section{DIFFICULTIES ENCOUNTERED}

XX. The outstanding difficulty which the Board encountered is that it had to pave every inch of its way with self-created precedent. The "General Botha" is the first institution of its kind which has been established in South African waters, and the institution had to be established upon lines adaptable to the conditions suitable to the country. The public from the outset displayed an unfamiliarity as to the principles upon which such an institution should be established. Some were under the impression that it was an institution for correcting unruly boys whose parents were unable to control them at home, others that it should be confined to poor whites and no educational standard laid down, and, until Mr. Davis gave up his idea of the establishment of a ship at Durban for the training of boys for officer cadetship in the Mercantile Marine, the "General Botha" was considered for a time, even by the Board, as an institution only for the training of seamen for the Mercantile Marine and the Royal Navy. Then, like uncharted rocks, the institution was continually meeting with expressions of disapproval from the "antimoored-training-ship" critic who was only in favour of the "General Botha" being used as a cruising-trading-training ship. There were others who did not favour a ship at all but a shore training college, and some again who preferred the ship to be a Defence Department training ship. All these problems had to be carefully considered by the Board in addition to seeking a nautical staff for the ship, laying down what the period of training should be, and providing a scheme for the selection and conditions of entry for boys. The ship had also to be carefully surveyed and practically gutted in order to prepare her for the accommodation of 150 boys. The labours in connection with the work made very liberal demands upon the private time of the members of the Board. Educational authorities had to be approached 
with a view to the continuance of the non-technical education and a curriculum of both branches of the education had to be drawn up and considered as well as schoolmasters appointed. Rationing of the ship, coal contract, provision of water, the installating of light and pumping power, equipment, clothing, medical, hospital and dental treatment had also to be carefully gone into, each item with a strict view to businesslike economy. Then there were such questions as berthing of the ship, dock rent, insurance, drafting regulations for the administration of the ship, and contracts of service for the various members of the staff in order to place the whole institution upon a footing of discipline. Many other subjects had also to be carefully considered which have involved both considerable time and labour on the part of the members of the Board. The system followed was that of the appointment of committees consisting of those members of the Board more particularly qualified in each subject of enquiry.

XXI. As to the constructive problems enumerated in the opening of the preceeding paragraph, it was decided by the Board that to put a corrective-disciplinary or reformatory complexion upon South Africa's first and only nautical training institution would have damned it as a South African nautical institution from the start. The Board, therefore, took very stringent precautions against even troublesome boys finding their way into the ship, by requiring that in the conditions of entry a guarantee of good character (vide Form E, under Regulation No. 5) should be furnished in respect of every boy. Should unruly boys find their way into the ship it will be the policy of the Board to see that they do not remain on board to create a bad influence upon other boys or to lower the reputation of the institution in the eyes of the seafaring world. The Board decided, however, not to make the institution a "cadet ship," but that every boy should be made to work, from the bottom rung of the ladder, without any false pride about certain work being below his dignity. The boys are, therefore, trained as seamen and dressed as such, but before the conclusion of the course it is proposed in respect of those boys who pass out and are recommended as cadets that the question may be considered of making them cadets previous to leaving the "General Botha" and continuing their career at sea. So far as concerns the argument that the ship should be an ocean-going trading-training ship, an armoured cruiser is not adapted to carry cargo, and, if it were, most of our boys are too young, as it is not the practice to employ boys at sea under the age of 15 years. Neither could the continuance of the boys' nontechnical education be carried out on an ocean-going training ship without the extra cost of engaging a crew to man the ship, and, in any case, owing to the curriculum the boys have to go through during the two years' course very little time would be left for them to take their part in running the ship.

There is something to be said for a shore college with a ship attached, but the donor, who has been trained in the Mercantile Marine himself, preferred a moored ship as a best means of stimulating in a boy the real sense of the sea which, as most South African boys are without sea experience, Mr. Davis rightly thought would be more easily aroused by the boy being actually afloat. However, there was the gift, a training college afloat, which removed the necessity for incurring the building of a college. There are over 18 nautical Mercantile Marine training institutions in England, of which only a few are shore colleges. The remainder, with the exception of two ships belonging to one of the shipping lines, all are moored training ships. The two best known institutions, namely the schoolships "Conway" and "Worcester," are both moored ships, and it is upon the lines of these and other training ships that the Board proposes to run the "General Botha," for which a good reputation should be built up out of the excellent material which the two chief white races of South Africa can provide. 
The above is only a rough outline of the difficulties which the Board has had to face, but no doubt after two or three years, when the institution has been thoroughly established, the labours of the Board will be lightened.

\section{CONCLUSION}

XXII. The pressing need of a South African nautical training institution has been demonstrated by the 1,005 applications which have been received for the first year's 75 vacancies. At the present rate at which the applications are being received for the next year's 75 vacancies, they are likely to exceed 1,005 .

One of the great problems of South Africa is the finding of suitable employment for her youth. What future is there more worthy of the great sea traditions of the two white peoples from which we have sprung than the manly and honourable calling of the sea.

South Africa is backward in all that relates to the sea. It is only now that she is beginning to realise the necessity of taking steps towards the fulfilment of her obligations in this regard whether for commerce or defence. We have been content to let others officer and man the ships upon which the trade of our country depends. Even our South African owned merchant ships are not officered or manned by South Africans. Is it not time, therefore, that we made some progress in the fulfilment of what are our rightful obligations as a young nation praiseworthily yearning to be self-reliant?

In the course of years there is no reason why every merchant ship engaged in the South African trade should not be both officered and manned principally, if not wholly, by South Africans, and also why South Africans serving in the Royal Navy, whether as officers or seamen, should not be drafted to the ships belonging to the Africa Squadron.

It is hoped that with the continuation of the necessary export trade of South Africa, a mercantile marine fleet owned by South Africans and operating from South Africa as its home ports will spring up and that, with the steady turn-out of navigators produced from the boys who have gone through their training in the "General Botha," sufficient boys will be at that time forthcoming to provide the officers and men to man such fleet.

From reports received and from the personal observation of every technical and non-technical member of the Board, the boys are taking to their new life in a manner well befitting the fine sea traditions of the two races and, what is more, they are happy in their new surroundings, notwithstanding the fact of the sudden change it must have been to the boys from the interior, many of whom had never seen the sea before.

XXIII. The Board strongly recommends to the Union Government the introduction of a Merchant Shipping Act and the consequent establishment of an Union Marine Board in order that South African boys in training in South Africa, upon completion of the necessary service at sea, can be examined in South Africa for each class of sea certificate, and that the standard of such certificates shall be at least equal to those issued by the Imperial Board of Trade and acknowledged by such Board, thereby giving the Union sea certificates a worldwide value and standard.

The Board also strongly urges that when a Union Merchant Shipping Act is introduced into Parliament that the Government will see that it is to the benefit of South African shipping to have uniformity of practice with that of the other parts of the Empire whose shipping lines are engaged in the South African trade. 
XXIV. The first Board has been working during its year under less favourable conditions than the second Board will most probably have to face and no doubt, with the benefit of the first year's experience standing to their credit, the second Board will effect many improvements both from a technical and economical standpoint.

Office of Board of Control,

Cape Town.

8th July, 1922.

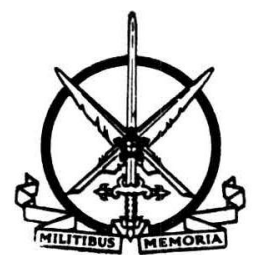




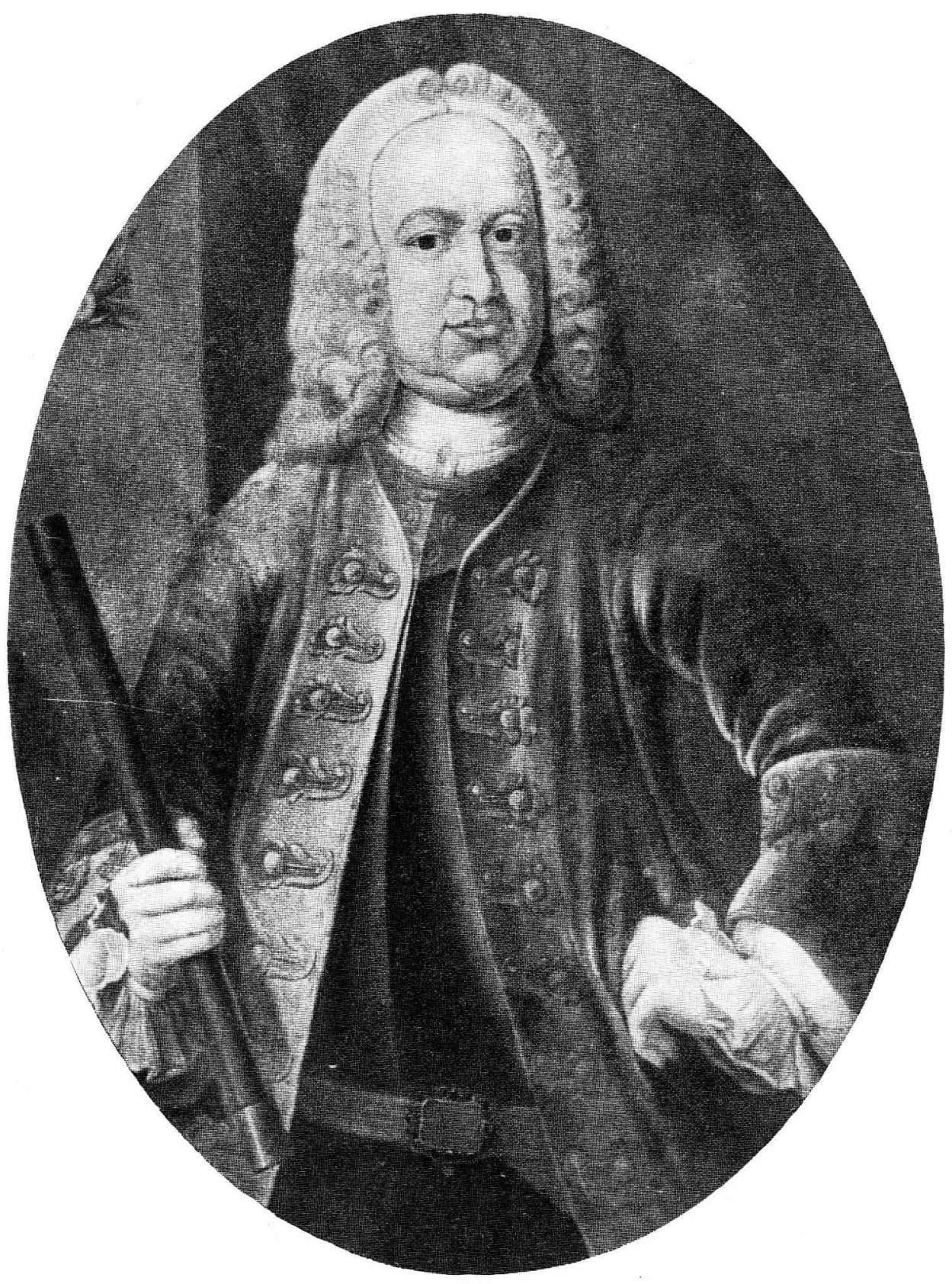

Governor General Gustaaf Willem, Baron van Imhoff (1705-1750), Governor of Ceylon (1736-1740), Governor General of Netherlands East India, Lieutenant General of the Armed Forces of the Netherlands Republic, who inspected the Cape Colony in 1743.

Goewerneur-generaal Gustaaf Willem, Baron van Imhoff (1705-1750), goewerneur van Ceylon (1736-1746), Goewerneur-generaal van Nederlands Oos-Indië, luitenani-generaal van die krygsmag van die Nederlandse Republiek, wat die Kaapkolonie in 1743 geïnspekteer het. 